\title{
Everyday Life and Everyday Communication in Coronavirus Capitalism
}

\author{
Christian Fuchs
}

University of Westminster, London, christian.fuchs@uti.at, http://fuchsc.net

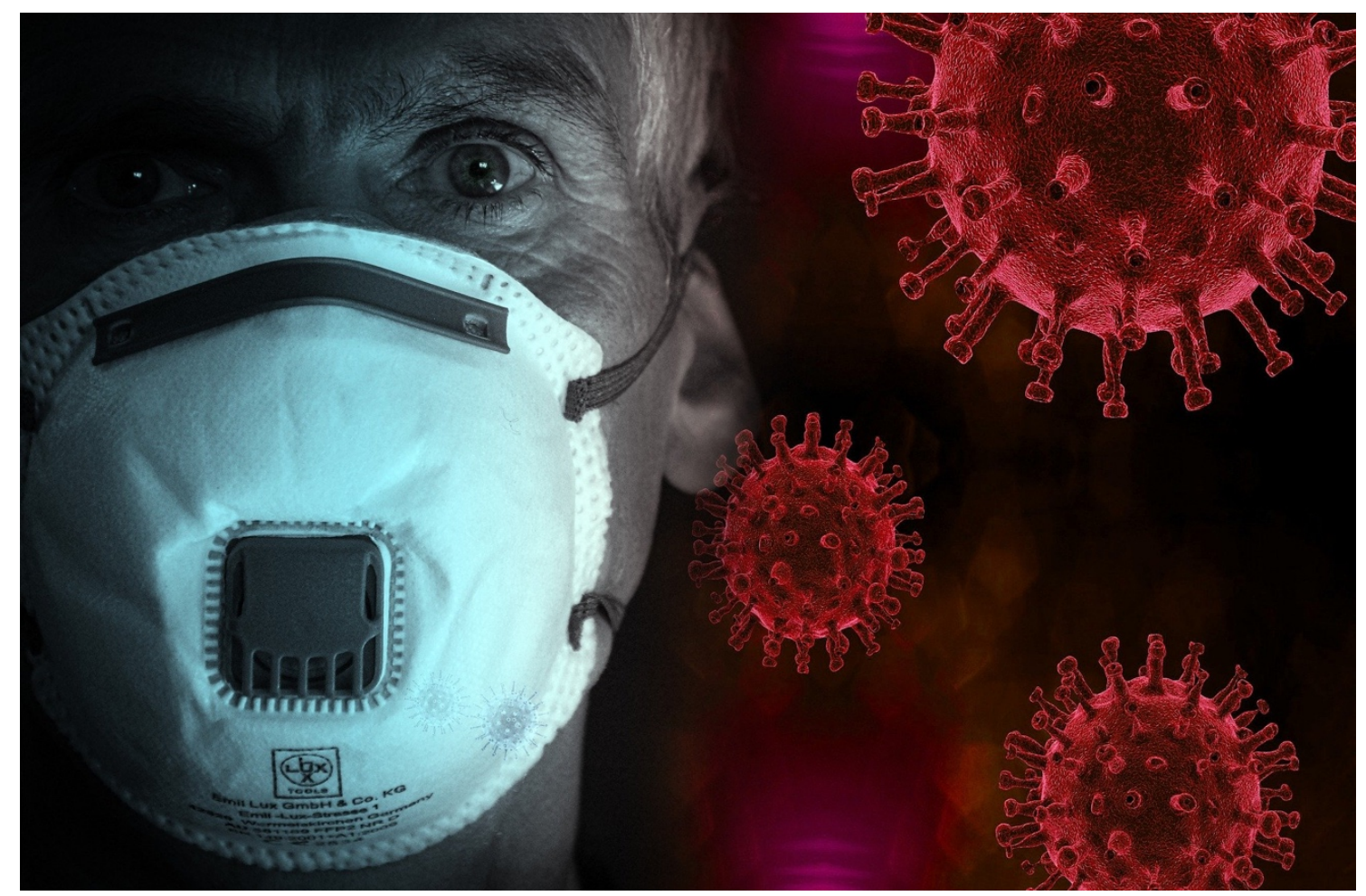

Abstract: In 2020, the coronavirus crisis ruptured societies and their everyday life around the globe. This article is a contribution to critically theorising the changes societies have undergone in the light of the coronavirus crisis. It asks: How have everyday life and everyday communication changed in the coronavirus crisis? How does capitalism shape everyday life and everyday communication during this crisis?

Section 2 focuses on how social space, everyday life, and everyday communication have changed in the coronavirus crisis. Section 3 focuses on the communication of ideology in the context of coronavirus by analysing the communication of coronavirus conspiracy stories and false coronavirus news.

The coronavirus crisis is an existential crisis of humanity and society. It radically confronts humans with death and the fear of death. This collective experience can on the one hand result in new forms of solidarity and socialism or can on the other hand, if ideology and the far-right prevails, advance war and fascism. Political action and political economy are decisive factors in such a profound crisis that shatters society and everyday life.

Keywords: coronavirus, COVID-19, everyday life, everyday communication, critical theory, critical theory of communication, means of communication, communication technology, capitalism, ideology, fake news, false news, crisis, public health, Henri Lefebvre, David Harvey 


\section{Introduction}

The coronavirus (COVID-19) is a highly infectious respiratory disease. Its name stems from the fact that it looks like a crown under the microscope. The virus is highly contagious and has a death rate that is multiple times higher than the one of seasonal flu. Common symptoms include fever, a dry cough, shortness of breath, and extreme tiredness. The majority of cases have a mild development, but in a certain share of cases a severe pneumonia develops that can be life-threatening.

The first patient suffering from the disease was identified on 1 December 2019 in Wuhan, a city with more than 11 million inhabitants in China's Hubei province. By the end of January 2020, there were almost 12,000 reported cases in Mainland China ${ }^{1}$. Given the networked and global character of contemporary societies, the coronavirus spread globally within a short time period. "Earlier experience had shown that one of the downsides of increasing globalization is how impossible it is to stop a rapid international diffusion of new diseases. We live in a highly connected world where almost everyone travels. The human networks for potential diffusion are vast and open" (Harvey 2020). On 11 March 2020, the World Health Organization declared the coronavirus to be a pandemic. On 29 March 2020, there were 638,146 confirmed coronavirus cases in a total of 203 countries that had resulted in 30,105 deaths $^{2}$.

As a reaction to the virus threats to humankind and human lives, many countries introduced wide-ranging public health-measures such as the shutdown of public life and social distancing measures. This paper is a contribution to the social theory analysis of coronavirus crisis' implications for society. It asks: How have everyday life and everyday communication changed in the coronavirus crisis? How does capitalism shape everyday life and everyday communication during this crisis?

Section 2 focuses on how social space and everyday communication have changed due to the coronavirus crisis. Section 3 focuses on the communication of ideology in the context of coronavirus by analysing the communication of coronavirus conspiracy stories and false coronavirus news.

\section{Everyday Communication and Sociality in the Coronavirus Crisis}

As long as there is no vaccination against coronavirus, the virus poses a danger to the lives of all humans and the societies they form because it is highly contagious and has a relatively high death rate that is manifold times higher than the one of seasonal flu.

In order to fight the pandemic, WHO (2020) recommends "that social distancing and quarantine measures need to be implemented in a timely and thorough manner. Some of the measures that countries may consider adopting are: closures of schools and universities, implementation of remote working policies, minimizing the use of public transport in peak hours and deferment of nonessential travel".

\section{Boris Johnson's Social Darwinism}

As a reaction to the pandemic, social distancing was implemented as a public health measure in many countries. Some have taken strict measures such as curfews, whereas others only recommended social distancing but did not enforce it by law. Some countries have shifted their policies. Boris Johnson's Conservative government

${ }^{1}$ Data source: https://en.wikipedia.org/wiki/2019\%E2\%80\%9320 coronavirus pandemic in mainland China

${ }^{2}$ Data source: WHO, https://www. who.int/emergencies/diseases/novel-coronavirus-2019, accessed on 30 March 2020. 
in the UK first took a laissez-faire approach. It did not shut down public life. It later took measures common in many countries continental Europe such as the closure of schools and non-essential businesses, the prohibition of public events, and the order that people have to stay at home.

In a press conference on March 12, Johnson said that due to coronavirus "many more families are going to lose loved ones before their time". At the same time, he did not take measures such as shutting down public life as other countries had already done at the same point of time. The strategy that he announced together with his scientific and medical advisors was based on not containing the virus but letting it spread until "herd immunity" is reached. Chief Medical Officer Chris Whitty argued that the "our top planning assumption is up to 80 percent of the population being infected". Given the UK has 66 million inhabitants and the death rate of coronavirus is on average one percentage, this implies letting more than 500,000 people die from coronavirus in order to reach what in medical jargon is called herd immunity. In a Sky News interview, Chief Scientific Advisor Patrick Vallace defended this approach by saying that "of course we do face the prospect of, as the Prime Minister said yesterday, an increasing number of people dying. [...] This is a nasty disease"3.

Johnson and his chief medical and chief scientific advisor chose a social Darwinist approach where the fittest survive and the government tolerates that others die although public health measures could reduce the amount and share of deaths. Charles Darwin's half-cousin Francis Galton (1822-1911) argued that society should be based on "the workings of Nature by securing that humanity shall be represented by the fittest" (Galton 1909, 42). Just like the Thatcherism that the Tories have advanced preaches and practices survival of the fittest companies in the capitalist economy, Johnson and his advisors planned to use the same principle as population policy. The implication is that those who are old, weak, and ill are sacrificed. In a radically neoliberal society such as the United Kingdom and the USA, the Darwinist Alfred Russel Wallace concept of nature is applied to society: in the coronavirus crisis, the "best organised, or the most healthy, or the most active, or the best protected, or the most intelligent, will inevitably, in the long run, gain an advantage over those which are inferior in these qualities; that is, the fittest will survive" (Wallace 1889/2009, 123).

\section{Social Distancing}

Humans are social and societal beings. They live in and through social relations in society. Communication is the process of the production and reproduction of sociality, social relations, social structures, social systems, and society (Fuchs 2020a). In a social relation, at least two humans make sense of each other's actions. Each of them interprets what the other one is doing, which leads at least to new thoughts and potentially results in changes of the social system. The measure of social distancing practiced as a response to the coronavirus crisis doesn't mean the dissolution but the radical reorganisation of social relations. Humans avoid face-to-face social relations and substitute them by mediated social relations, in which communication is organised with the help of the telephone, social media, messenger and video communication software such as WhatsApp, Telegram, Zoom, Skype, Panopto, Blackboard Collaborate, Jitsi, Discord, etc. Social distancing isn't an avoidance of communication, but the substitution of face-to-face communication that bears the risk of contagion by mediated com-

${ }^{3}$ https://www.youtube.com/watch?v=2XRc389TvG8 
munication. Mediation becomes a strategy of both avoidance and survival. Social distancing is not a distancing from the social and other humans, but communication and sociality at a distance.

In 2020, billions of humans experienced and practiced a radical rupture and reorganisation of their social life. In modern society, we organise our everyday life as social practices that take place in distinct social systems, where we repeatedly in a routinised manner spend certain time periods together with others in order to achieve certain goals. Key social systems of our everyday life include the home, the workplace, and educational organisations (nursery, school, university). And there are public spaces accessible to everyone where we spend leisure time, meet others, commute from one place to another one, or organise other aspects of our everyday life. Such spaces include parks, playgrounds, cafés, trains, buses, the underground, shops, etc.

The division of labour and activities means that humans spend certain times of the day in particular spaces. An example is work in an office or factory from Monday to Friday between 9am and 5pm. This means that space and time are zoned into particular time periods spent at certain places. The flexibilization, globalisation, digitalisation, individualisation, and neoliberalization of capitalist society have transformed the space-time of everyday life. More and more people work from different spaces, including their home and public spaces, at a variety of times. The workplace, the home, and public spaces have partly converged. The boundaries between leisure time and labour time, play and labour, consumption and production, the office and the home, etc. have become blurred. For many people, this tendency has meant an increase of their labourtime and the extension of the logic of capital into spheres outside of the traditional workplace. More and more people have had to work more in order to survive, but have only done so in precarious ways.

\section{The Radical Transformation of the Space-Time of Everyday Life}

The coronavirus crisis brought about a radical transformation of the space-time of everyday life. Workplaces and public spaces shut down. The physical and social differentiation of the spaces of everyday life collapsed. Workplaces and schools suddenly completely converged with the home as the space of everyday life. The blurring and convergence of social spaces that had been advanced by neoliberalism was suddenly taken to its extreme. The intermediary spaces of public life, where we used to spend leisure time and transit times in cafés, restaurants, parks, nature, public transport, etc. emptied out, which created ghost towns and urban ghost spaces.

Politicians had to decide between two basic policy options in light of the coronavirus crisis, namely to either radically disrupt everyday life and ask the majority of citizens to stay at home or to minimally disrupt everyday life. The first option tries to save human lives by reducing the direct communication and direct social relations as far as possible and thereby inevitably creates an economic crisis. The second option keeps up direct communication and direct social relations, which risks human lives in order to try to avoid an economic crisis.

In an existential crisis such as the coronavirus crisis, neoliberal political strategies choose to keep most businesses open. In contrast, socialist government strategies shut all non-essential businesses that are not needed to guarantee the survival of society. In the first strategy, human life and well-being stands above economic interests. In the second strategy, economic growth and profitability is put before human life. 
Social space is structured and regionalised into specific locales. These are timespace locations, zones, stations, and domains such as homes, streets, cities, workplaces, schools, nurseries, parks, shops, restaurants, cafés, means of public transport, etc. "Locales refer to the use of space to provide the settings of interaction, the settings of interaction in turn being essential to specifying its contexuality. [...] Locales may range from a room in a house, a street corner, the shop floor of a factory, towns and cities, to the territorially demarcated areas occupied by nation-states. But locales are typically internally regionalized, and the regions within them are of critical importance in constituting contexts of interaction" (Giddens 1984, 118).

A locale is a particular physical or virtual space that is used at particular time, typically in a routinised manner, which implies repetition, for social actions and communication that have a particular goal. Space-time is organised in the form of demarcated and bounded zones or regions (locales) that are the physical, spatial and temporal context of specific types of action and communication. Locales are the places and physical settings of humans' communicative practices.

In the coronavirus crisis, the social spaces and locales of work, leisure, education, the public sphere, the private sphere, friendships, family converge in the locale of the home. The home is at the same time workplace, family and private space, school, nursery, leisure space, natural space, a public space from where we connect to friends and professional contacts, etc. Social spaces converge in the home. In this convergent social space, it can easily become difficult to organise everyday life by breaking up time into small portions of which each is dedicated to specific activities in a routinised manner. In the coronavirus crisis, the home has become the supra-locale of everyday life.

Whereas daytime used to be for many individuals working time, at the time of the coronavirus crisis it has to be simultaneously working time, play time, educational time, family time, shopping time, housework time, leisure time, care time, psychological coping time, etc. The convergence of social spaces in the home is accompanied by the convergence of time periods dedicated to specific activities. The result is that activities that humans usually perform in different social roles at different times in different locales converge in activities that are conducted in one universal, tendentially unzoned and unstructured space-time in one locale, the home.

\section{The Overburdening of the Individual}

This convergence can easily result in an overburdening of the individual who cannot manage multiple social roles at the same time in one locale. The situation is made worse by the exceptional psychological burdens that the coronavirus crisis causes, where individuals worry about the lives of their family, friends and themselves, have to think of how to organise everyday activities such as shopping and going out without risking their life and others' lives, have to cope with not being physically close to their family members, parents and friends, dedicate time to supporting old, weak and ill people from their families and communities who self-isolate, etc. In such a crisis, lots of time is survival time, time used for activities that secure immediate physical, psychological, and social survival. Routine activities become challenging tasks to which significant amounts of time need to be dedicated.

Survival work shapes everyday life in the coronavirus crisis. Given that direct communication is limited, more time needs to be spent on organising communication at a distance. There are times where individuals are not able to properly continue and "function" because they have to cope with fears of death, illness, and the future. In times of 
crisis, humans like to come together with their closest companions in order to help and support one another. In the coronavirus crisis, physical proximity of larger groups is discouraged because it increases the risks of contagion, illness, and death. Social distancing puts psychological burdens on many humans because they cannot be physically close to some or many of their loved ones. Mediated communication can provide some emotional support, but lacks the capacity of touching, feeling, smelling, hugging, etc. one another. You can say nice words to a friend or relative via a webcam, but you cannot look him or her into the eyes, which is part of empathetic communication. Physical proximity is an important aspect of care that is missing in the coronavirus crisis, which puts additional psychological burdens on individuals. It is much more difficult to communicate emotions, love, solidarity, and empathy in mediated communication than in face-to-face communication.

Houseworkers have traditionally had to deal with multiple types of work, including care, education, cleaning, cooking, shopping, etc., at the same time in the locale of the home. In a sense, the coronavirus crisis is a process of radical mass housewifization that confines work, social action, and communication to the locale of the home. This condition that has been characteristic for houseworkers since a long time (Mies, Bennholdt-Thomsen and Werlhof 1988).

It is decisive how the state acts in such a situation of profound emergency. There is a continuum of state action ranging from neoliberal action to socialist action. Neoliberal state action tolerates unemployment and precarity of workers and is only concerned with bailing out companies. It does not secure the social security, livelihood, income, rent payments, and survival of the working class. Socialist state action in contrast secures the survival of the working class by measures such as an unconditional basic income during crisis time, the continuation of wage payments for workers and freelancers, rent freezing, etc.

Socialist crisis action makes sure that humans have the time and resources needed to survive the crisis without becoming poor, indebted, bankrupt, etc. It recognises the need of humans for sufficient time during which they engage in survival work. It provides the material foundations needed for survival work.

Neoliberal crisis action tolerates an increase of poverty, misery, debt, precarity, homelessness, unemployment etc. in order to reorganise society in the interest of capital in a state of emergency. Thinking this logic to its end implies that neoliberal crisis management establishes a state-organised dictatorship of capital that enslaves the impoverished, indebted, and precarious working class that struggles to survive. The coronavirus crisis is a rupture and existential crisis of society that poses both potentials for the development of socialism and solidarity on the one side and slavery and fascist dictatorship on the other side.

\section{Social Space, Everyday Life, and Everyday Communication in the Coronavirus- Crisis}

Based on the French philosopher Henri Lefebvre's (1974/1991) theory of space, the critical theorist David Harvey (2005) provides a typology of social space (see table 1). Using Lefebvre's distinction between perceived, conceived, and lived spaces as three dimensions of space, Harvey distinguishes between physical space, representations of space, and spaces of representation. He adds to Lefebvre's theory the distinction between absolute, relative, and relational space. Spaces are absolute in that they are locales that have certain physical boundaries. They are relative because objects are placed in them that have certain distances from each other. And they are relational 
because these objects stand in relations to each other. In society, humans produce and reproduce social space by a dialectic of social practices and social structures. The cells in table 1 describe particular aspects of social space.

\begin{tabular}{|l|l|l|l|}
\hline & $\begin{array}{l}\text { Physical space } \\
\text { (experienced } \\
\text { space) }\end{array}$ & $\begin{array}{l}\text { Representations of } \\
\text { space (conceptualised } \\
\text { space) }\end{array}$ & $\begin{array}{l}\text { Spaces of representa- } \\
\text { tion } \\
\text { (lived space) }\end{array}$ \\
\hline $\begin{array}{l}\text { Absolute } \\
\text { space }\end{array}$ & physical locale & $\begin{array}{l}\text { symbols, maps and } \\
\text { plans of physical locales }\end{array}$ & $\begin{array}{l}\text { locales as social spaces } \\
\text { where humans live, work, } \\
\text { and communicate }\end{array}$ \\
\hline $\begin{array}{l}\text { Relative } \\
\text { space } \\
\text { (time) }\end{array}$ & $\begin{array}{l}\text { humans in a physi- } \\
\text { cal locale }\end{array}$ & $\begin{array}{l}\text { symbols used and mean- } \\
\text { ings created by humans } \\
\text { in physical locales }\end{array}$ & $\begin{array}{l}\text { humans as social actors } \\
\text { acting in social roles }\end{array}$ \\
\hline $\begin{array}{l}\text { Relational } \\
\text { space } \\
\text { (time) }\end{array}$ & $\begin{array}{l}\text { social relations of } \\
\text { humans in a physi- } \\
\text { cal locale }\end{array}$ & $\begin{array}{l}\text { language as social and } \\
\text { societal structure }\end{array}$ & $\begin{array}{l}\text { communicative practices } \\
\text { that produce and repro- } \\
\text { duce social relations, soci- } \\
\text { ality, and social spaces }\end{array}$ \\
\hline
\end{tabular}

Table 1: David Harvey's (2005) typology of social space

Table 2 shows how social spaces are changing and organised in the coronavirus crisis.

\begin{tabular}{|l|l|l|l|}
\hline & $\begin{array}{l}\text { Physical space } \\
\text { (experienced } \\
\text { space) }\end{array}$ & $\begin{array}{l}\text { Representations of } \\
\text { space (conceptualised } \\
\text { space) }\end{array}$ & $\begin{array}{l}\text { Spaces of representa- } \\
\text { tion } \\
\text { (lived space) }\end{array}$ \\
\hline $\begin{array}{l}\text { Absolute } \\
\text { space }\end{array}$ & $\begin{array}{l}\text { the home as the } \\
\text { supra-locale }\end{array}$ & $\begin{array}{l}\text { plans and strategies of } \\
\text { how to use the supra-lo- } \\
\text { cale of the home for the } \\
\text { organisation of everyday } \\
\text { life }\end{array}$ & $\begin{array}{l}\text { the home as the domi- } \\
\text { nant social spaces and } \\
\text { supra-social space } \\
\text { where humans simulta- } \\
\text { neously organise multi- } \\
\text { ple aspects of their life } \\
\text { and work, convergence } \\
\text { of absolute spaces in } \\
\text { the home }\end{array}$ \\
\hline $\begin{array}{l}\text { Relative } \\
\text { space } \\
\text { (time) }\end{array}$ & $\begin{array}{l}\text { humans stay pre- } \\
\text { dominantly in one } \\
\text { locale, their } \\
\text { homes }\end{array}$ & $\begin{array}{l}\text { symbols used and } \\
\text { meanings created by } \\
\text { humans in the supra-lo- } \\
\text { cale of the home }\end{array}$ & $\begin{array}{l}\text { convergence of humans' } \\
\text { social roles in the supra- } \\
\text { space of the home }\end{array}$ \\
\hline $\begin{array}{l}\text { Rela- } \\
\text { tional } \\
\text { space } \\
\text { (time) }\end{array}$ & $\begin{array}{l}\text { social relations at } \\
\text { a physical dis- } \\
\text { tance organised } \\
\text { via communica- } \\
\text { tion technologies } \\
\text { between home lo- } \\
\text { cales }\end{array}$ & $\begin{array}{l}\text { language as social } \\
\text { structure }\end{array}$ & $\begin{array}{l}\text { the convergence of hu- } \\
\text { mans' communicative } \\
\text { practices in the conver- } \\
\text { gent space and under } \\
\text { conditions of the conver- } \\
\text { gent time of the home, } \\
\text { mediation of the conver- } \\
\text { gence of space-time by } \\
\text { communication technol- } \\
\text { ogies }\end{array}$ \\
\hline
\end{tabular}

Table 2: Social space in the coronavirus crisis 
In the coronavirus crisis, humans are largely confined to the physical space of the home, for which certain organisational strategies are needed so that everyday life can be organised from the home. Humans experience, conceptualise, live and thereby also produce social space-time in manners that make social spaces converge in the supratime-space of the home. Communication technologies play a decisive role in organising everyday life from the locale of the home in the coronavirus crisis.

Everyday life refers to social practices within the totality of society (Lefebvre 2002, 31). Everyday life is an "intermediate and mediating level" of society (45). Lefebvre identifies three dimensions of everyday life: natural forms of necessity, the economic realm of the appropriation of objects and goods, and the realm of culture (62). So Lefebvre sees nature, the economy, and culture as the three important realms of everyday life. What is missing is the realm of politics, where humans take collective decisions that are binding for all and take on the forms of rules. The critique of everyday life analyses how humans live, "how badly they live, or how they do not live at all" (18). Lefebvre argues that in phases of fundamental societal change, "everyday life is suspended, shattered or changed" (109). The coronavirus crisis has suspended, shattered, and necessitated the reorganisation of the practices, structures, and routines of everyday life.

\begin{tabular}{|l|l|}
\hline The lived (le vécu) & The living (le vivre) \\
\hline individual & group \\
\hline experience, knowledge, doing & context, horizon \\
\hline practices & structures \\
\hline present & presence \\
\hline
\end{tabular}

Table 3: Lefebvre's distinction between the lived and the living (source: Lefebvre 2002, 166, 216-218)

Lefebvre distinguishes between the lived (le vécu) and the living (le vivre) as two levels of everyday life (see table 3). Figure 1 shows a model of everyday life.

At the level of lived reality, humans produce social objects through communicative practices. They do so under the conditions of the living, i.e. structural conditions that enable and constrain human practices, production, and communication. The level of living life consists of an interaction of social structures, social systems, and social institutions. All structures, systems and institutions have economic, political, and cultural dimensions. In many social systems, one of these dimensions as dominant so that we can differentiate between economic, political and cultural structures/systems/institutions. At the level of lived life, humans relate to each other through communicative practices. These communicative practices are the foundations of the production, reproduction, and differentiation of economic, political, and cultural structures/systems/institutions that condition human practices. There is a dialectic of the living and the lived in any society. This is a dialectic of human subjects and social objects. 


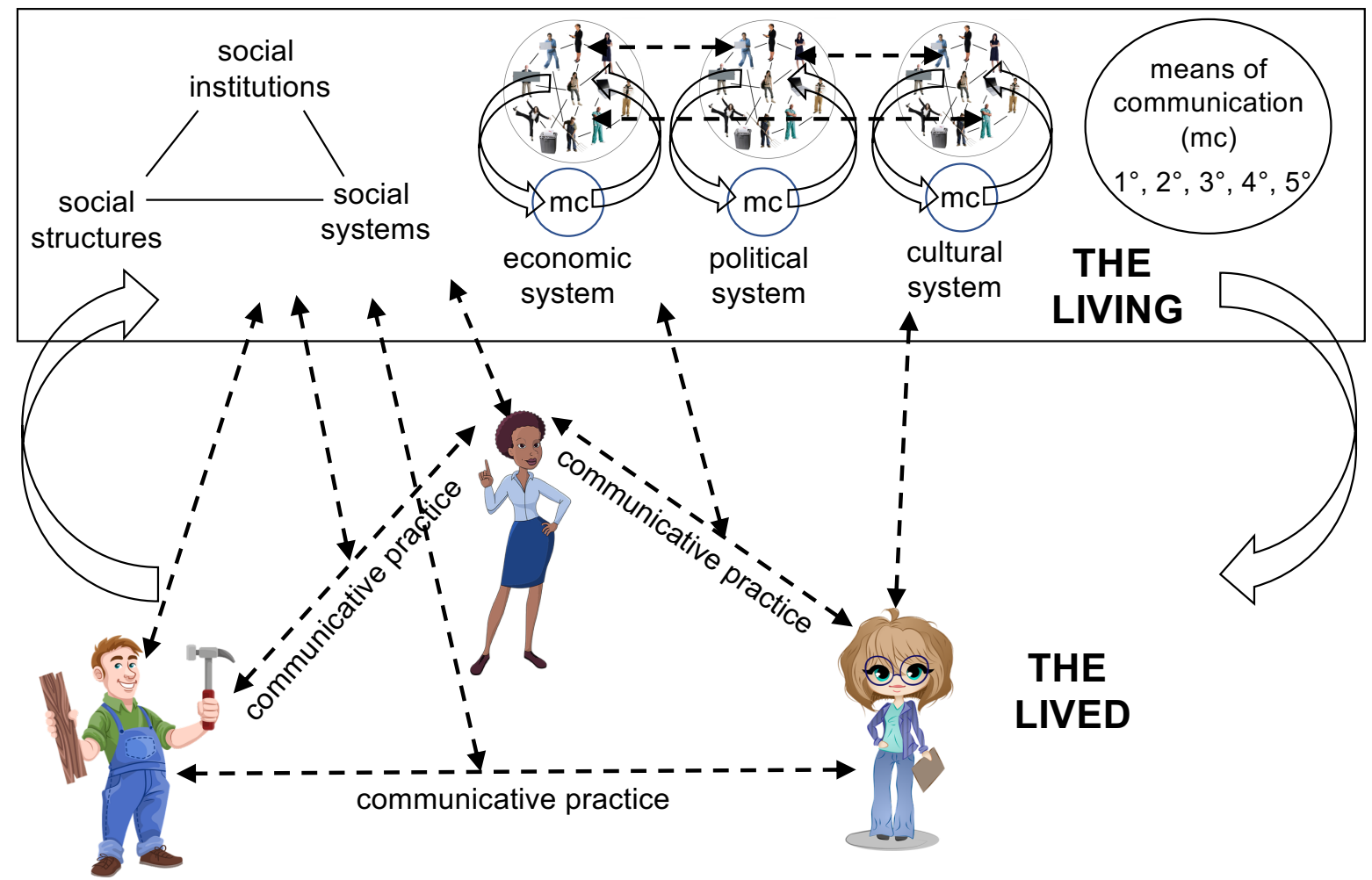

Figure 1: Everyday life and everyday communication

Means of communication mediate the dialectic of objects and subjects and the relations between humans. We can distinguish five types of the means of communication (table 4).

\begin{tabular}{|l|l|l|}
\hline & Role of mediation by technology & Examples \\
\hline $\begin{array}{l}\text { Primary communica- } \\
\text { tion technologies }\end{array}$ & $\begin{array}{l}\text { Human body and mind, no media } \\
\text { technology is used for the production, } \\
\text { distribution, reception of information }\end{array}$ & $\begin{array}{l}\text { Theatre, concert, perfor- } \\
\text { mance, interpersonal com- } \\
\text { munication }\end{array}$ \\
\hline $\begin{array}{l}\text { Secondary communi- } \\
\text { cation technologies }\end{array}$ & $\begin{array}{l}\text { Use of media technology for the pro- } \\
\text { duction of information }\end{array}$ & $\begin{array}{l}\text { Newspapers, magazines, } \\
\text { books, technologically pro- } \\
\text { duced arts and culture }\end{array}$ \\
\hline $\begin{array}{l}\text { Tertiary communica- } \\
\text { tion technologies }\end{array}$ & $\begin{array}{l}\text { Use of media technology for the pro- } \\
\text { duction and consumption of infor- } \\
\text { mation, not for distribution }\end{array}$ & $\begin{array}{l}\text { CDs, DVDs, tapes, records, } \\
\text { Blu-ray disks, hard disks }\end{array}$ \\
\hline $\begin{array}{l}\text { Quaternary commu- } \\
\text { nication technolo- } \\
\text { gies }\end{array}$ & $\begin{array}{l}\text { Use of media technology for the pro- } \\
\text { duction, distribution and consumption } \\
\text { of information }\end{array}$ & $\begin{array}{l}\text { TV, radio, film, telephone, } \\
\text { Internet }\end{array}$ \\
\hline $\begin{array}{l}\text { Quinary communica- } \\
\text { tion technologies }\end{array}$ & $\begin{array}{l}\text { Digital media prosumption technolo- } \\
\text { gies, user-generated content }\end{array}$ & Internet, social media \\
\hline
\end{tabular}

Table 4: Five types of the means of communication

Figure 2 visualises the transformation of everyday life and everyday communication at the time of the coronavirus crisis. Humans isolate themselves and therefore avoid direct communicative relations. This circumstance is visualised at the level of the lived by enclosed individuals and small enclosed groups. Dense networks of direct communication and direct social relations are suspended. At the structural level of the lived, the economic, political and cultural dimensions are not organised as separate locales 
but tend to converge in the social system of the home that takes on the form of a supralocale from where economic, political and the cultural life are organised and structured from a distance. Humans spend the vast majority of their time in physical isolation in their homes, from where they access and organise social structures, systems, and institutions at a distance by making use of secondary, tertiary, quaternary, and quinary means of communication. The use of the primary means of communication, namely face-to-face communication, is avoided. Whereas under regular conditions humans organise the economy, politics, and culture in the form of separate social systems that they access in everyday life by commuting to different specialised physical locales, in the coronavirus crisis specialised physical locales are suspended. These systems' structural social roles are preserved: a multitude of humans who are located in the physical locales of their homes organises these systems at a distance with the help of mediated communication. Humans hardly communicate with each other face-to-face but through mediating communication technologies.

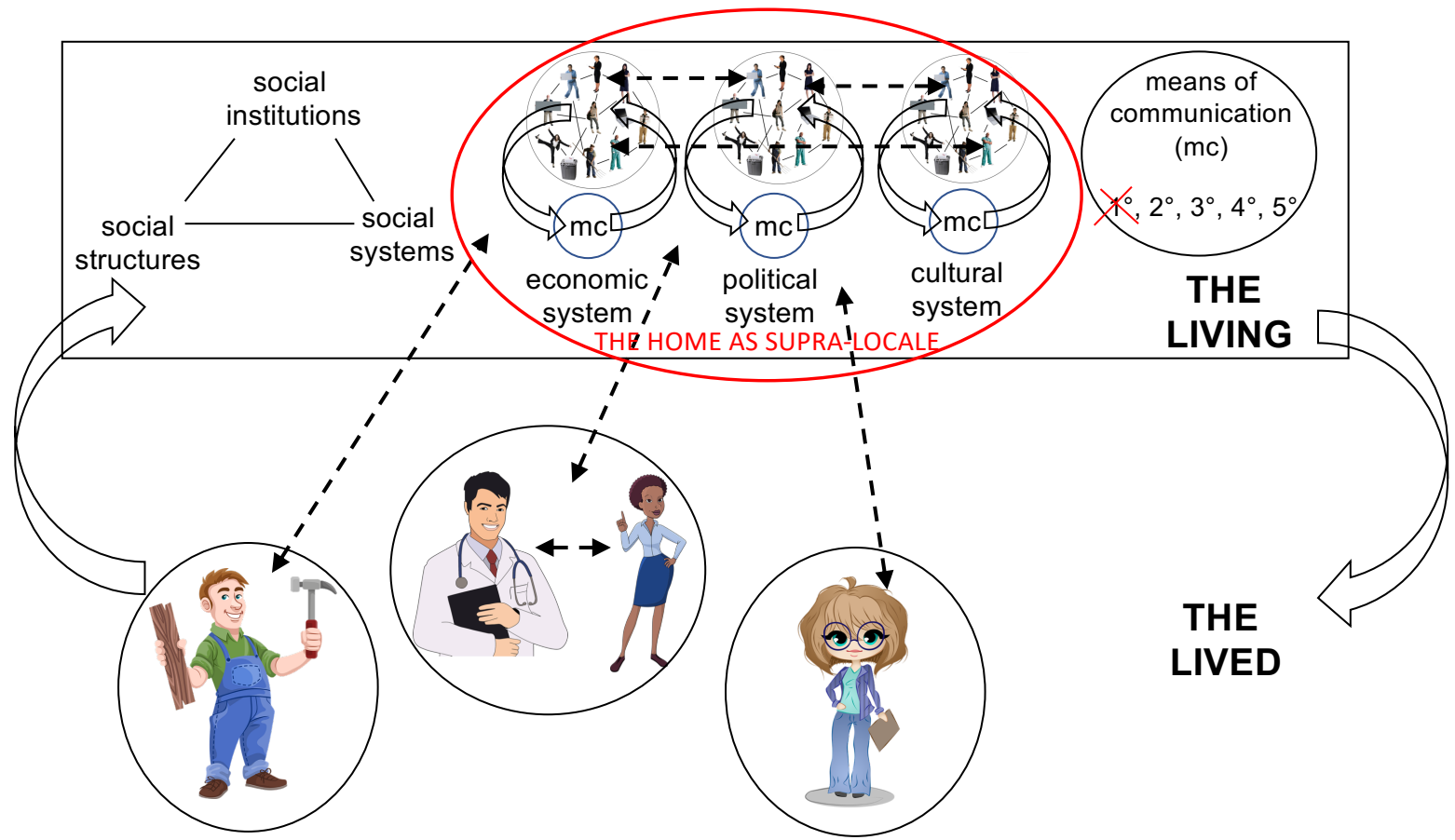

Figure 2: Everyday life and everyday communication in the coronavirus crisis

\section{The Coronavirus Crisis as Deceleration of Everyday Life?}

In the coronavirus crisis, most people traverse only smaller physical distances and fewer goods are transported so that everyday life is decelerated and comes to a relative standstill. There are fewer people for overall less time on the streets, in public and intermediate spaces. At the same time, the number of social activities and communicative practices taking place from the home and conducted from there at a distance massively increases. As a consequence, communication networks such as the Internet and mobile phone networks are used at a maximum capacity. The thinning out of social activity in public spaces corresponds to the thickening and multiplication of social activities taking place in the home and locally. The coronavirus crisis deglobalizes and therefore localises everyday life. 
The German sociologist Hartmut Rosa (2020b) argues that the corona virus crisis means "forced deceleration" . He argues that there is a "massive deceleration of real physical life, where on the one hand feels silenced and excluded but on the other hand one discovers new forms of solidarity and new forms of amenability" (Rosa 2020b). Rosa is rather optimistic about the consequences of the coronavirus crisis. On the one hand he sees the loss of ontological security and trust so that "relationships become suspect" 6 and there is "growing alienation"7 (Rosa 2020a). On the other hand, he sees new opportunities for resonance, a condition where humans enter into unalienated relations with others and the world: "We have time. Suddenly we can hear and experience what is happening around us: Maybe we indeed hear the birds, look at the flowers and greet the neighbours. Hearing and answering instead of domination and control are the beginning of a relation of resonance from which something novel can emerge" 8 (Rosa 2020a).

\section{Socialism or Barbarism}

The coronavirus crisis certainly means that humans make fewer direct social relations, commute much less, live quite locally, and traverse less physical distance. But this does not necessarily imply the deceleration of social life. The speed of social life has to do with the amount of experiences we make per unit of time. Even if we do not move at all, we can live in a high-speed society where vast amounts of information are rapidly processed and large numbers of decisions are taken and many actions are performed per unit of time. Whether or not the coronavirus crisis is an opportunity for generally slowing down the pace of modern life is first and foremost a question of political economy. It depends on whether or not governments take measures that allow humans to survive without depending on constantly having to perform labour under precarious conditions and provide material foundations that help to avoid an overburdening of the individual from the convergence of social spaces, social times, and social roles.

What humans realise in the coronavirus crisis is that life, wellbeing, health, and survival are not self-evident. This crisis is a radical confrontation of the individual and society by death. The collective experience of the fear of death can create new forms of solidarity in society and elements of socialism. The "threat of viral infection also gave a tremendous boost to new forms of local and global solidarity, plus it made clear the need for control over power itself. [...] the present crisis demonstrates clearly how global solidarity and cooperation is in the interest of the survival of all and each of us" (Žižek 2020). But if right-wing demagogues manage to ideologically manipulate these fears, then the realisation of such potentials might be destroyed and fascist potentials

\footnotetext{
${ }^{4}$ Translation from German: „Zwangsentschleunigung”.

${ }^{5}$ Translation from German: „Dem steht eine massive Verlangsamung im realen physischen Leben gegenüber. Wo man sich einerseits stillgestellt und ausgeschlossen fühlt, andererseits plötzlich neue Formen von Solidarität und neue Formen von Zugewandtheit entdeckt".

6 Translation from German: „Beziehungen werden suspekt“.

7 Translation from German: "wachsende Entfremdung“.

${ }^{8}$ Translation from German: „Wir haben Zeit. Wir können plötzlich hören und wahrnehmen, was um uns herum geschieht: Vielleicht hören wir wirklich die Vögel und sehen die Blumen und grüßen die Nachbarn. Hören und Antworten (statt beherrschen und kontrollieren): Das ist der Beginn eines Resonanzverhältnisses, und daraus, genau daraus kann Neues entstehen".
} 
that divide society and advance dictatorship, genocide, war, inhumanity, and mass murder might be realised. The coronavirus crisis radicalises the perspectives for the future of society. It makes it more likely that we are either heading towards socialism or barbarism.

\section{Coronavirus, Risk Society, Class Society}

Coronavirus and other risks can also hit the rich and powerful such as Prince Charles, Prince Albert, Boris Johnson, Rand Paul, Michel Barnier, or Tom Hanks. But this circumstance does not imply, as the German sociologist Ulrich Beck (1992) claims, that we live in a classless world risk society where existential risks affect everyone equally beyond status and class.

The rich and powerful can purchase access to the best private doctors and hospitals and can escape from risks, whereas the poor, workers, and everyday people suffer the consequences of privatisation and universal commodification, which means they are more likely to die. The coronavirus crisis once more shows that the risk society is first and foremost a class society.

\section{The Most Vulnerable}

In the coronavirus crisis, those worst hit and most vulnerable are humans who do not have a home to which they can retreat such as the homeless and refugees who are on the run or live in refugee camps. It is very difficult for these groups to shield themselves from the virus. In the coronavirus crisis, politicians can either protect these vulnerable groups by creating and providing suitable shelters that allow social distancing or abandon them by not providing support, which implies that many vulnerable individuals will die. Humans in developing countries face the problem that they often live in overcrowded spaces in poor metropolises or in areas that lack access to water, soap, hospitals, doctors, etc. Protective measures such as social distancing and washing one's hands can therefore be more difficult to organise in developing countries. The lack of material foundations of protection therefore can especially affect and harm humans in poor countries and regions.

\section{The Working Class in the Coronavirus Crisis}

Life and work have been radically transformed in the coronavirus crisis. There is a group of workers who cannot work from home and from a distance. They depend on a differentiation of social spaces and direct social relations in order to produce. Examples include personal services (cooks, cleaners, waiters, bartenders, hairdressers, travel attendants, childcare workers, etc.), manufacturing labour, construction labour, agricultural work, food processing labour, garment labour, drivers, transport labour, refuse labour, elementary labour etc.

Many of these occupations have low and medium skills and rather low wages. Given that many workplaces were shut down in the coronavirus crisis, lower-paid and lower-skill workers who depend on direct social relations and the access to work spaces outside their homes faced a high likelihood of becoming unemployed. For example, in Austria the number of the unemployed rose from around 400,000 to 550,000 within ten days in March 2020 (APA 2020). The largest share of the newly unemployed belonged to the economic sectors of accommodation, gastronomy, and construction (APA 2020). 
In the coronavirus crisis, especially highly qualified white-collar workers can continue to work from their homes. This includes both employees and freelancers. Think for example of the activities of architects, managers, scientists, engineers, designers, teachers, academics, writers, artists, analysts, administrators, accountants and financial workers, marketing and public relations workers, software developers and other digital workers creating digital goods and services, lawyers, translators, secretaries, typists, call centre agents, consultants, etc. Such workers may in principle be able to work from home. In many countries, there is a general guideline or rule in the coronavirus crisis that says that those who can conduct their work from home should or have to do so.

There are two main problems such workers face:

a) they may face social and psychological overburdening when trying to work in the home that at the time of an existential crisis is a convergent space of manifold activities, including care work, educational work, wage-labour, survival work, etc.

b) given the relative shutdown of society, there is a reduced demand for services, which means that there might be diminishing sources of income for many homeworkers.

It is decisive how governments support white-collar workers and other workers in the coronavirus crisis. Neoliberal strategies put capital and economic growth first, which means that white-collar workers are expected to work at normal capacity and pace from home and cannot rely on special support. Socialist strategies put survival, health, well-being, and social security first and therefore support white-collar workers and other workers materially so that they do not face the existential danger of material ruin.

\section{Critical Infrastructures}

There is a number of occupations in the organisation of critical infrastructures that are necessary for society's survival in an existential crisis. Such foundational work is performed by, for example, doctors, nurses, care workers, midwives, paramedics, pharmacists, psychologists, firefighters, public transport workers, journalists, public service media workers, police officers, food producers, food processing workers, food delivery and transport workers, supermarket workers, post office and delivery workers, sanitation workers, pharmaceutical workers, manufacturing and assemblage workers producing medical equipment, utility workers, telecommunications workers, emergency workers, legal sector workers, etc.

Workers in critical infrastructural sectors face a higher risk of falling themselves ill because in their work they have more direct social contacts than others. Think for example of doctors and nurses treating COVID-19 patients in hospitals. It is important that governments and organisations do everything that is possible in order to provide protective equipment, measures, and working conditions that protect these workers. A particular problem during the coronavirus crisis was the lack of protective equipment, as a result of which many nurses and doctors contracted the virus. Such workers show a high level of solidarity that is needed for securing the survival of society and humankind. It is insufficient that they are publicly lauded as heroes. The crucial importance of their work should be acknowledged not just symbolically but also economically and socially by e.g. special bonus payments that are not just symbolic, special retirements benefits, etc.

Especially in emergency situations, the market provision of key infrastructures is bound to fail because the commodity form operates based on the profit principle and 
not on the principle of human interest. Insofar as key infrastructures are not public services, establishing public ownership combined with worker control is a measure that puts humanism over the logic of capital accumulation. Neoliberalism has in countries such as the USA and the United Kingdom prevented or undermined the public provision of health care. As a consequence, there is a lack of resources in (including personnel and physical resources) and of individuals' access to the health care system. In a state of exception such as the coronavirus crisis, dysfunctional health care systems multiply the number of deaths. It has become evident that universal health care and public ownership of the care sector are of crucial importance for guaranteeing wellbeing for everyone. The writer and activist Mike Davis (2020) argues in this context that the coronavirus pandemic shows that "capitalist globalization now appears to be biologically unsustainable in the absence of a truly international public health infrastructure". Bernie Sanders commented in this context in the following way on the coronavirus crisis:

"[M]illions of people are now demanding that we have a government that works for all. What role should the campaign play in continuing that fight to make sure that health care becomes a human right, not a privilege, that we raise the minimum wage to a living wage, et cetera, et cetera. people now understand that it is incomprehensible that we remain the only major country on earth not to guarantee health care to all, that we have an economy which leaves half of our people [...] living paycheck to paycheck. [...] What kind of system is it where people today are dying, knowing they're sick, but they're not going to the hospital because they can't afford the bill that they'll be picking up?" (Sprunt 2020).

The implication of Sander's programme is that countries struck by coronavirus should "hire enough people to identify COVID-19 home-by-home right now and equip them with the needed protective gear, such as adequate masks. Along the way, we need to suspend a society organized around expropriation, from landlords up through sanctions on other countries, so that people can survive both the disease and its cure" (Wallace et al. 2020). Coronavirus makes evident that the world needs to realise a global right to public healthcare, i.e. public healthcare at a high standard for all. "The spiral form of endless capital accumulation is collapsing inward from one part of the world to every other. The only thing that can save it is a government funded and inspired mass consumerism conjured out of nothing. This will require socializing the whole of the economy [...] without calling it socialism" (Harvey 2020).

\section{The Social Distancing of Old, Weak and III Individuals}

Old people and people suffering from cardiovascular disease, chronic respiratory diseases, diabetes, cancer or having a weakened immune system are at a particular risk to die from coronavirus. Many governments therefore have recommended or mandated that at-risk groups should stay at home and isolate themselves. This, however, entails the problem that reduced direct social contacts might be experienced as a psychological burden. The use of communication technologies for staying in touch with loved ones and communities is not a fix for the lack of direct social contacts, although it is a means for providing certain forms of emotional support. Older people, however, face a digital divide. This group's physical, motivational and skills access to digital technologies such as computers, the Internet, laptops, tablets, mobile phones, apps, social media, etc. is significantly lower than in the younger generation. In 2019, 98 
percent of EU citizens aged 16-24 were Internet users, whereas only 60 percent of those aged 65-75 uses the Internet. In the age group of 65-75, 31 percent had low and 2 percent no digital skills $2019^{9}$.

Given the digital divide, older people face a particular risk of feeling lonely and depressed as a result of social distancing. Whereas neoliberal strategies simply tell pensioners to isolate without supporting measures, a socialist strategy devises measures in order to alleviate the psychological burdens of social isolation. Examples include social and community services that provide food, install easy-to-use communication technologies in at-risk group members' homes, engage in daily contacts with atrisk individuals, etc.

\section{Children, Youth, and (E-)Learning in the Coronavirus-Crisis}

In the coronavirus crisis, many countries shut nurseries, primary and secondary schools, as well as universities. As a consequences, children and youth needed to stay at home with their parents. The general expectation has been that teaching continues at a distance making use of e-mail, video conferencing, messaging systems, and a variety of e-learning technologies.

The first problem that arises is that children, and especially small children, need lots of attention, which conflicts with parents being able to work from home. Parents have to act not just as workers and carers, but also as teachers. A socialist strategy has to put childcare and well-being over labour. The implication is that in an existential crisis of society, wages should be continued to be paid and subsidised by governments without performance expectations. States of emergency are radical ruptures of society and everyday day. One cannot expect that life, work, and education can continue as normal. Therefore, also the educational performance expectations of pupils and students should be suspended or put at a minimum level. One feasible option is that learning materials and support are provided but there are no exams and all students and pupils automatically pass.

The second problem is that e-learning that is purely mediated and virtual tends to be inefficient and difficult to organise. Therefore, blended learning where virtual learning at a distance is combined with face-to-face learning sessions has become the generally accepted standard in e-learning. Blended learning "is the full integration of faceto-face and online activities. [...] Blended learning can include the blending of individual and collaborative activities, modes of communication (verbal and written), and a range of face-to-face and online courses that constitute a blended program of studies" (Garrison 2011, 75-76). Blended learning "represents a significant conceptual and practical breakthrough in enhancing the quality of teaching and learning [...] The great advantage of blended learning is that while it is transformative, it builds upon traditional ideals of communities of learners and familiar face-to-face learning" (Garrison 2011, 82).

The radical virtuality of e-learning in the coronavirus crisis easily reaches limits and causes problems. Keeping up the performance principles of grading, success, and failure under such difficult learning conditions is counterproductive to the cultural and social development of young people.

\section{Global Cities and Rural Areas in the Coronavirus Crisis}

\footnotetext{
${ }^{9}$ Data source: Eurostat, https://ec.europa.eu/eurostat
} 
Global capitalism created a power gap between global cities on the one side and rural areas on the other side. Global cities are urban spatial agglomerations of capital, labour-power, companies, banks, infrastructure, corporate headquarters, service industries, international financial services, telecommunication facilities, etc. Global cities include, for example, New York, London, Tokyo, Paris, Frankfurt, Zurich, Amsterdam, Los Angeles, Sydney, São Paulo, Mexico City, and Hong Kong. "The more globally the economy becomes, the higher the agglomeration of central functions in a relatively few sites, that is, the global cities" (Sassen 1991, 5). "The need to minimize circulation costs as well as turnover times promotes agglomeration of production within a few large urban centers which become, in effect, the workshops of capitalist production" (Harvey 2001, 245). Geographical expansion goes hand in hand with geographical concentration (Harvey 2001, 246).

Whereas wealth and power are concentrated in global cities, there is a lack of resources, people, and infrastructures in many rural areas, which is a source of social problems. In the coronavirus crisis, people living in densely populated global cities are at a disadvantage in comparison to those in rural areas. There is a lack of natural spaces and accessible gardens in global cities, which makes it hard for families and individuals living in such cities to endure quarantine and social isolation. It is especially difficult for those who have kids but live in small apartments without access to a garden. In addition, the high population density in global cities makes it more likely and easier that the virus spreads than in sparsely populated rural areas. People in rural areas are less likely to contract the coronavirus and they have better access to nature, which makes it easier to cope with quarantine measures.

"High-density human populations would seem an easy host target. It is well known that measles epidemics, for example, only flourish in larger urban population centers but rapidly die out in sparsely populated regions. How human beings interact with each other, move around, discipline themselves, or forget to wash their hands affects how diseases get transmitted" (Harvey 2020).

In the coronavirus crisis, the unequal geography has partly been reversed in respect to the absolute and relative number of illnesses and death. Rural areas certainly can face the disadvantage of less equipped and advanced hospitals, but their inhabitants are less likely to contract coronavirus than the inhabitants of global cities.

Section 2 focused on the analysis of a variety of aspects of everyday life and everyday communication in the coronavirus crisis. It outlined profound changes of how space-time is organised in societies struck by the pandemic. It became evident that the well-being of everyday people depends on political economy and what policies governments takes in response to the crisis. Political responses to the crisis range on a continuum between neoliberalism on the one side and socialism on the other side. The next section will focus on how and what type of ideology is communicated in the context of the coronavirus crisis.

\section{The Communication of Coronavirus Conspiracy Stories and False News}

Slavoj Žižek (2020) warns against not taking the coronavirus serious:

"Both alt-right and fake Left refuse to accept the full reality of the epidemic, each watering it down in an exercise of social-constructivist reduction [...] Trump and 
his partisans repeatedly insist that the epidemic is a plot by Democrats and China to make him lose the upcoming elections, while some on the Left denounce the measures proposed by the state and health apparatuses as tainted by xenophobia and, therefore, insist on shaking hands, etc. Such a stance misses the paradox: not to shake hands and to go into isolation when needed IS today's form of solidarity".

Downplaying and denying the seriousness of coronavirus is an ideological dimension of the crisis. The spreading of fake news is another manifestation of ideology in the state of exception.

\section{False News}

There is no generally accepted definition of fake news. The core of many definitions is that fake news is factually false news that is circulated online, predominantly on social media, lacks journalistic professional norms, and tries to systematically and deliberately mislead and misinform (Fuchs 2021, chapter 7). Some observers prefer to use the terms mis- or disinformation. Some of those who spread fake news, such as Donald Trump, use the term in order to try to attack credible news sources. Based on the tradition of ideology critique that stresses that false consciousness is an expression of ideological attempts to manipulate the public's perception of reality, a critical theory approach to fake news should better use the term "false news". False news is an expression of a highly polarised political landscape, where lies are used for trying to manipulate election results and decision-making (Fuchs 2020b).

The Cambridge Analytica scandal was a typical manifestation of false news (ibid.). In false news culture, facts are declared to be wrong and lies are declared to be true. There is a distrust of experts, liberals, and socialists. There is a distrust towards facts and rationality and a belief that truth is what one finds ideologically and emotionally agreeable. Demagogues try to scapegoat experts and political opponents by claiming that they form an elite that hates the people and considers them as silly. Demagogues spreading false information claim that they stand on the side of the people who share their ideology and that elites deliberately bias and misrepresent reality.

The coronavirus crisis created a state of exception in many countries and parts of the world. Suddenly billions of people's everyday life was disrupted and had to be reorganised. They have had to fear for their lives and the lives of friends and family. They have had to think of how to organise their children's care, how to manage to live in isolation, how to best organise shopping, how to deal with the situation's psychological stress, etc. The situation of crisis, uncertain futures, collective shock, and the collective fear of death characteristic for the coronavirus emergency is a futile ground for the spread of false news. We do not know exactly what the motivations of those spreading false coronavirus news have been, but it is possible to provide an overview of the main themes of false stories that have circulated at the time of the global spread of the pandemic $^{10}$.

\section{Types of False Coronavirus News}

There are two main types of false coronavirus news stories:

${ }^{10}$ Data source: https://en.wikipedia.org/wiki/Misinformation related to the 2019\%E2\%80\%9320 coronavirus pandemic, accessed on 27 March 2020. 
a) false news related to the origin of coronavirus;

b) false news about how the virus is contracted and can be killed.

The first type focuses on how coronavirus is produced, the second on how it circulates and can be destroyed.

Fake news stories about the origin of coronavirus:

- COVID-19 is a Chinese biological weapon developed in the Wuhan Institute of Technology.

- The Chinese government collaborated with other forces, such as the Democratic Party in the USA or the North Korean government, in releasing the virus in order to bring down Donald Trump.

- The CIA created and spread COVID-19 as a biological weapon in order to challenge the economic and political power of China, Russia, or Iran.

- Israel developed and spread COVID-19 in order to create a financial market crisis and financially benefit from the resulting volatility.

- Israel or Jews such as the Rothschild family manufactured COVID-19 in order to seize world power.

- Chinese spies stole COVID-19 from a virus research laboratory in Canada.

- COVID-19 is part of a population control strategy developed by Bill Gates and the UK-government funded Pirbright Institute.

- Donald Trump created the pandemic in order to arrest or kill paedophiles, political opponents, and Hollywood actors.

- Eating meat is the cause of coronavirus.

Fake news stories about contracting and killing coronavirus:

- A COVID-19 vaccine already exists.

- Cocaine cures coronavirus.

- Africans are resistant.

- $5 \mathrm{G}$ wireless networks caused the outbreak of coronavirus.

- Pets spread coronavirus.

- Vinegar kills coronavirus.

- Drinking boiled ginger or lemon water or cow urine kills coronavirus.

- Gargling bleach kills coronavirus.

- Going to the sauna kills coronavirus.

- Using a hair dryer kills coronavirus.

- Taking medicinal herbs kills coronavirus.

- The Holy Communion protects one from coronavirus.

- Using silver-infused toothpaste kills coronavirus.

- Spiritual healing kills coronavirus.

\section{Breitbart, Rush Limbaugh, and False Coronavirus News}

Let us have a look at an example of a false coronavirus news story. Breitbart is a farright propaganda website. On 27 March 2020, it was the $256^{\text {th }}$ most accessed web platform in the world ${ }^{11}$. This means that Breitbart stories reach a very large audience. On 24 February 2020, Breitbart ran a story about right-wing radio talk show host Rush

${ }^{11}$ Data source: https://www.alexa.com/siteinfo/breitbart.com, measured as a 90-day trend, accessed on 27 March 2020. 
Limbaugh. The Rush Limbaugh Show is with an average of more than 15 million listeners not just the USA's most-listened-to talk radio show, but also the country's mostlistened-to radio programme ${ }^{12}$. Created in 1988, this show is a prototype and main manifestation of far-right broadcasting. It airs on weekdays and around 600 local radio stations broadcast it.

The Breitbart article's title was "Limbaugh: Coronavirus Being 'Weaponized' to Bring Down Trump"13. Limbaugh claimed that "probably is a ChiCom [Chinese communist] laboratory experiment that is in the process of being weaponized. All superpower nations weaponize bioweapons. [...] It looks like the coronavirus is being weaponized as yet another element to bring down Donald Trump. I want to tell you the truth about the coronavirus"14. "Some people believe that it got out on purpose, that the ChiComs have a whole lot of problems based on an economy that cannot provide for the number of people they have. So losing a few people here and there [is] not so bad for the Chinese government" 15 . "The coronavirus is an effort to get Trump"16.

So what Limbaugh claims is that China manufactured the coronavirus in order to target the USA with a bioweapon and weaken Trump's political position by bringing about many deaths. Fact-checking organisation PolitiFact analysed the claims made in this episode of The Limbaugh Show and concluded that the claims were false ${ }^{17}$.

Breitbart also made use of its social media channels in order to spread Rush Limbaugh's conspiracy theory. At the time of writing, Breitbart had more than 4 million followers on Facebook, 1.2 million followers on Twitter, 620k followers on Instagram, and $160 \mathrm{k}$ subscribers on YouTube ${ }^{18}$. On 25 February 2020, Breitbart posted a link to the Limbaugh-story on its Facebook page (see figure 3). On 28 March, the Facebook posting had been shard 900 times, and had received 4,200 emotional reactions and 1,200 comments. At the same point of time, 2,279 users had commented on the news article on the Breitbart platform to which the Facebook posting linked.

12 Data source: https://en.wikipedia.org/wiki/List of most-listened-to radio programs, accessed on 27 March 2020.

${ }^{13}$ https://www.breitbart.com/clips/2020/02/24/limbaugh-coronavirus-being-weaponized-tobring-down-trump/

${ }_{14}$ Ibid.

${ }^{15}$ https://www.youtube.com/watch?v=Yp3EBJFKnGo

16 Ibid.

${ }^{17}$ https://www.politifact.com/factchecks/2020/feb/27/rush-limbaugh/fact-checking-rushlimbaughs-misleading-claim-new-l

${ }^{18}$ Data source: https://www.facebook.com/Breitbart, https://twitter.com/BreitbartNews, https://www.instagram.com/wearebreitbart/, https://www.youtube.com/channel/UCmgnsaQIK1IR808Ebde-ssA 
Rush Limbaugh: "It looks like the coronavirus is being weaponized as yet another element to bring down Donald Trump."

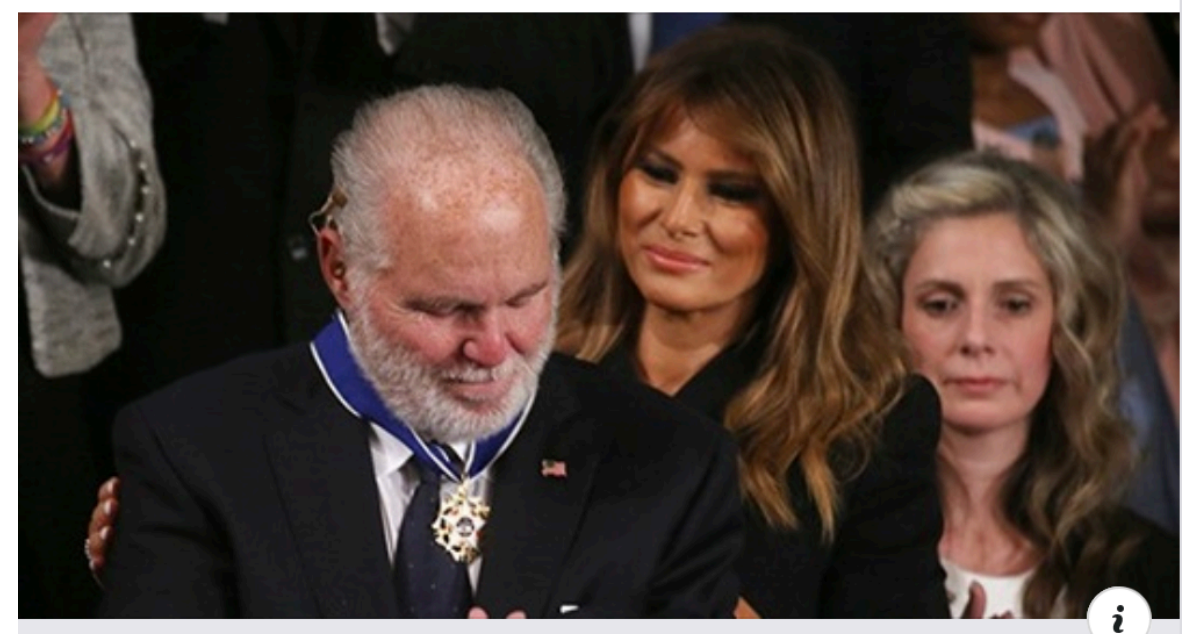

BREITBART.COM

Limbaugh: Coronavirus Being 'Weaponized' to Bring Down Trump

(1). $0.2 \mathrm{~K}$

1.2K Comments 900 Shares

Figure 3: Breitbart's spreading of Rush Limbaugh's coronavirus conspiracy on social media, https://www.facebook.com/Breitbart/posts/rush-limbaugh-it-looks-like-thecoronavirus-is-being-weaponized-as-yet-another-e/10164646988865354/, accessed on 28 March 2020

The example of Rush Limbaugh's conspiracy claim that China manufactured coronavirus in order to bring down Donald Trump shows how the far-right uses a combination of different media in order to spread false news in the public. In this particular case, the broadcast medium of radio was used in order to launch a false news story. Breitbart used the Internet and social media in order to amplify the false news story. Broadcast media and social media that allow commenting and sharing together amplified the audience reach and thereby the spread of coronavirus false news.

Like all conspiracy stories, Limbaugh's claims lack evidence and ignore the findings of experts. He builds on the ideological conviction and moral outrage of Trump-supporters who think that there is a big conspiracy where intellectuals, socialists, liberals, and foreign countries try to attack the United States.

False news ignores scientific evidence. There are no indications that the coronavirus was manufactured by humans. The DNA sequences of the coronavirus (COVID19) are most closely related to viruses found in bats (Cohen 2020a, York 2020, Ye 2020, Zhou 2020). Based on environmental sampling, there is evidence that the virus was contracted from animals to humans at Wuhan seafood market (ibid.). Scientists found out that animals such as the pangolin could be the species mediating the infection between bats and humans (Cyranoski 2020, Lam et al. 2020). Andersen et al. (2020) write based on an analysis of the COVID-19-genome that they "do not believe that any type of laboratory-based scenario is plausible". 
Ignoring scientific evidence, a variety of conspiracy theories has emerged around COVID-19. "Speculations have included the possibility that the virus was bioengineered in the lab [Wuhan Institute of Virology] or that a lab worker was infected while handling a bat and then transmitted the disease to others outside the lab" (Cohen 2020 b). In a letter to leading medical journal The Lancet, 27 public health scientists "strongly condemn conspiracy theories suggesting that COVID-19 does not have a natural origin. [...] Conspiracy theories do nothing but create fear, rumours, and prejudice that jeopardise our global collaboration in the fight against this virus" (Calisher et al. 2020, e42). Scientists "overwhelmingly conclude that this coronavirus originated in wildlife” (Calisher et al. 2020, e42).

\section{Nationalism, Fascism, War}

The coronavirus pandemic is a crisis of humankind. The virus was transferred from animals to humans and given the global and mobile character of societies, it spread globally within three months causing many deaths. Given that contemporary societies are not nationally contained, but involve the international transport of goods and people and global travelling, a novel virus can originate in and spread globally from any part of the Earth. What the far-right tries to do is to deflect attention from the fact that the coronavirus crisis is a crisis of humanity that can only be overcome by global solidarity among and mutual aid of humans.

The far-right ideologizes the virus. They declare coronavirus to be a project designed and manufactured by single nations in order to weaken, attack, and try to destroy other nations. Their goal is to use the crisis situation in order to radicalise nationalism and spread nationalist hatred among the populations of different countries. It is not a rational assumption that a country such as China spreads a virus in its own country, which causes many deaths, in order to attack other countries. Coronavirus has caused many deaths in all parts of the world. Coronavirus ideology works by combining nationalism and conspiracy thinking. The far-right uses traditional mass media and social media in order to spread nationalism and hatred in the context of a crisis of humanity.

Donald Trump repeatedly spoke of coronavirus as the "Chinese virus" (Mangan 2020). The World Health Organization warned against this term, saying that viruses "know no borders and they don't care about your ethnicity, the color of your skin or how much money you have in the bank. So it's really important we be careful in the language we use lest it lead to the profiling of individuals associated with the virus" (Kopecki 2020). The danger of nationalist ideology in a state of exception and a crisis of humanity is that authoritarian characters such as Trump are prone to use violence, which can result in wars, nuclear attacks, the creation of a fascist state, etc.

There is a social dimension of the coronavirus crisis: there is a large number of persons who fall seriously ill or die. The relative standstill of society necessary for containing the virus translates into economic crisis. And there is a political dimension of the coronavirus crisis, where nationalism and ideology can bring about the rise of fascism and world war. Coronavirus is a natural disaster that threatens humanity. Irrational reactions such as nationalism, ideology, and violence pose a serious danger in such profound crises. The lack of solidarity and the displacement of solidarity by nationalism can turn a natural disaster that brings about a social and economic crisis into a political crisis that features war, mass killings, genocide, and fascism.

\section{Conclusion}


This paper asked: How have everyday life and everyday communication changed in the coronavirus crisis? How does capitalism shape everyday life and everyday communication during this crisis?

We can summarise the main findings:

\section{- Social distancing:}

The social distancing practiced during the coronavirus crisis isn't an avoidance of communication and social relations, but the substitution of face-to-face communication that bears the risk of contagion by mediated communication. Social distancing is not the distanciation from sociality and communication but rather sociality and communication at a distance.

\section{- The rupture of everyday life and everyday communication:}

The coronavirus crisis brought about a radical transformation of the space-time of everyday life and everyday communication. In this crisis, the social spaces and locales of work, leisure, education, the public sphere, the private sphere, friendships, family converge in the locale of the home. The home takes on the role of the supra-locale of everyday life from which humans organise society at a distance with the help of communication technologies. Activities that humans usually perform in different social roles at different times in different locales converge in activities conducted in one universal, tendentially unzoned and unstructured space-time in one locale, the home.

\section{- The danger of overburdening individuals:}

The convergence of space-time in the home characteristic for the coronavirus crisis can easily overburden the individual who cannot manage multiple social roles at the same time in one locale. Public health policies that unburden the individual are therefore of key importance for managing such a crisis.

\section{- Communication technologies as means of sociality at a distance:}

Communication technologies play an important role in the organisation of everyday social life under the exceptional conditions that the coronavirus crisis poses for society and individuals. Primary means of communication are by and large avoided. There is the wide use of mediated communication with the help of secondary, tertiary, quaternary and quinary means of communication. Face-to-face communication is replaced by mediated communication, which creates challenges because closeness, love, and emotions are hard to achieve and communicate in mediated communication. You cannot hug someone over the Internet.

\section{- Coronavirus and class structures:}

Although everyone can contract coronavirus, the social effects of the pandemic are unequally distributed along class structures. The poor, the old, the weak, and the ill are especially vulnerable and affected. Whereas some workers can continue to work from home but face the danger of overburdening activities and lack of demand, other workers lose their jobs and face the danger of destitution, unemployment, and homelessness.

\section{- Government measures:}

Government responses to the coronavirus crisis range on a continuum between neoliberalism and socialism. Neoliberal strategies could for example be found in the 
United Kingdom. They take a laissez-faire approach that avoids disrupting everyday life and put economic growth and the profit imperative over human interests and human lives. Everyone is left to themselves, which means that only the strong survive. Such responses make clear that neoliberalism is a form of social Darwinism. Socialist strategies are based on the idea of collective solidarity in fighting the pandemic. Measures are taken that minimise the death toll and try to safeguard a good life for everyone. Human interests and human lives are put over capitalist interests. The coronavirus crisis is an existential crisis of humanity and society. Socialist measures aim at providing resources and forms of relief to humans that allow them enough time for survival labour in order to better cope with the difficulties of the ruptures of everyday life and to be better able to reorganise routine activities, cope with fears and anxiety, support friends, family, and communities, etc.

\section{- False coronavirus news:}

The collective shock and the collective fear of death that emerged in the coronavirus crisis are a futile ground for the spread of false news about coronavirus.

\section{- Types of false coronavirus news:}

There are two main types of false coronavirus news stories:

a) false news related to the origin of coronavirus;

b) false news about how the virus is contracted and can be killed.

\section{- The far-right's communication of false coronavirus news:}

The far-right has taken advantage of the coronavirus crisis in order to spread nationalism and hatred by communicating false coronavirus news stories via traditional and social media.

\section{Socialism or Barbarism}

The coronavirus crisis is an existential crisis of humanity and society. It radically confronts humans with death and the fear of death. This collective experience can on the one hand result in new forms of solidarity and socialism. Humans realise that life, wellbeing, health and survival are their most important and most fundamental goods, that they need to take care of themselves and of each other, and that collective and global solidarity is needed in order to overcome the pandemic.

But on the other hand there is the danger of war and fascism. The biggest political danger of the coronavirus crisis is that the far-right uses the state of emergency in order to spread false news, nationalism, hatred, which can result in violence, warfare, dictatorship, genocide, and fascism. The coronavirus crisis radicalises the perspectives for the future of society. It makes it more likely that we are either heading towards socialism or barbarism. Just like hundred years ago, bourgeois society also today and in the coming time "stands at the crossroads, either transition to socialism or regression into barbarism" (Luxemburg 1916, 388). "In this hour, socialism is the only salvation for humanity" (Luxemburg 1971, 367).

\section{References}

Andersen, Kristian G. 2020. The Proximal Origin of SARS-CoV-2. Nature Medicine, https://doi.org/10.1038/s41591-020-0820-9 
APA (Austria Press Agency). 2020. 153.100 mehr Arbeitslose seit 15. März. Wiener Zeitung, 25 March 2020, https://www.wienerzeitung.at/nachrichten/wirtschaft/oesterreich/2055625153.100-mehr-Arbeitslose-seit-15.-Maerz.html

Beck, Ulrich. 1992. Risk Society: Towards a New Modernity. London: Sage.

Calisher, Charles et al. 2020. Statement in Support of the Scientists, Public Health Professionals, and Medical Professionals of China Combatting COVID-19. The Lancet 395: e42e43, https://doi.org/10.1016/S0140-6736(20)30418-9

Cohen, John. 2020a. Mining Coronavirus Genomes for Clues to the Outbreak's Origins. Science Magazine, 31 January 2020, https://www.sciencemag.org/news/2020/01/miningcoronavirus-genomes-clues-outbreak-s-origins\#

Cohen, John. 2020b. Scientists "Strongly Condemn" Rumors and Conspiracy Theories About Origin of Coronavirus Outbreak. Science Magazine, 19 February 2020, https://www.sciencemag.org/news/2020/02/scientists-strongly-condemn-rumors-and-conspiracy-theoriesabout-origin-coronavirus\#

Cyranoski, David. 2020. Mystery Deepens Over Animal Source of Coronavirus. Nature 579: 18-19.

Davis, Mike. 2020. In a Plague Year. Jacobin, 14 March 2020, https://jacobinmag.com/2020/03/mike-davis-coronavirus-outbreak-capitalism-left-international-solidarity

Fuchs, Christian. 2021. Social Media: A Critical Introduction. London: Sage. Third edition.

Fuchs, Christian. 2020a. Communication and Capitalism. A Critical Theory. London: University of Westminster Press.

Fuchs, Christian. 2020b. Nationalism on the Internet: Critical Theory and Ideology in the Age of Social Media and Fake News. New York: Routledge.

Galton, Francis. 1909. Essays in in Eugenics. London: The Eugenics Education Society.

Garrison, Randy D. 2011. E-Learning in the $21^{\text {st }}$ Century. A Framework for Research and Practice. New York: Routledge. Second edition.

Giddens, Anthony. 1984. The Constitution of Society. Outline of the Theory of Structuration. Cambridge: Polity.

Harvey, David. 2020. Anti-Capitalist Politics in the Time of COVID-19. Jacobin, 20 March 2020, https://jacobinmag.com/2020/03/david-harvey-coronavirus-political-economy-disruptions

Harvey, David. 2005. Space as Keyword. In Spaces of Neoliberalization, 93-115. Stuttgart: Franz Steiner Verlag.

Harvey, David. 2001. Spaces of Capital. Towards a Critical Geography. New York: Routledge.

Kopecki, Dawn. 2020. WHO Officials Warn US President Trump Against Calling Cornavirus the "Chinese Virus". CNBC, 18 March 2020, https://www.cnbc.com/2020/03/18/who-officials-warn-us-president-trump-against-calling-coronavirus-the-chinese-virus.html

Lam, Tommy Tsan-Yuk et al. 2020. Identifying SARS-CoV-2 Related Coronaviruses in Malayan Pangolins. Nature, https://doi.org/10.1038/s41586-020-2169-0

Lefebvre, Henri. 2002. Critique of Everyday Life. Volume II: Foundations for a Sociology of the Everyday. London: Verso.

Lefebvre, Henri. 1974/1991. The Production of Space. Malden, MA: Blackwell.

Li, Xiang et al. 2020. Bat Origin of a New Human Coronavirus: There and Back Again. Science China Life Sciences 63: 461-462, https://doi.org/10.1007/s11427-020-1645-7

Luxemburg, Rosa. 1971. Selected Political Writings of Rosa Luxemburg. New York, NY: Monthly Review Press.

Luxemburg, Rosa. 1916. The Junius Pamphlet. In Rosa Luxemburg Speaks, 371-477. New York: Pathfinder.

Mangan, Dan. 2020. Trump Blames China for Coronavirus Pandemic: "The Worls is Paying A Very Big Price for What They Did". CNBC, 19 March 2020, https://www.cnbc.com/2020/03/19/coronavirus-outbreak-trump-blames-china-for-virusagain.html 
Mies, Maria, Veronika Bennholdt-Thomsen, and Claudia von Werlhof. 1988. Women: The Last Colony. London: Zed Books.

Rosa, Hartmut. 2020a. Interview. Philosophie Magazin, 18 March 2020, https://philomag.de/auf-einmal-sind-wir-nicht-mehr-die-gejagten/

Rosa, Hartmut. 2020b. Interview. TAZ, 25 March 2020, https://taz.de/Soziologe-HartmutRosa-ueber-Corona/!5673868/

Sassen, Saskia. 1991. The Global City. Princeton, NJL Princeton University Press.

Sprunt, Barbara. 2020. Bernie Sanders on His Campaign: "It's Going to Be A Very Steep Road". NPR, 27 March 2020, https://www.npr.org/2020/03/27/822171139/bernie-sanderson-his-campaign-it-s-going-to-be-a-very-steep-road?t=1585500234287

Wallace, Alfred Russel. 1889/2009. Darwinism. Cambridge: Cambridge University Press.

Wallace, Rob, Alex Liebman, Luis Fernando Chavez and Rodrick Wallace. 2020. COVID-19 and Circuits of Capital. Monthly Review 72, https://monthlyreview.org/2020/03/27/covid19-and-circuits-of-capital/

World Health Organization (WHO). 2020. WHO Announces COVID-19 Outbreak a Pandemic. WHO, 12 March 2020, http://www.euro.who.int/en/health-topics/health-emergencies/coronavirus-covid-19/news/news/2020/3/who-announces-covid-19-outbreak-a-pandemic

Ye, Zi-Wei et al. 2020. Zoontic Origins of Human Coronavirus. International Journal of Biological Sciences 16 (10): 1686-1697.

York, Ashley. 2020. Novel Coronavirus Takes Flight From Bats? Nature Reviews Microbiology 18: 191.

Zhou, Peng et al. 2020. A Pneumonia Outbreak Associated With a New Coronavirus of Probable Bat Origin. Nature 579: 270-273.

Žižek, Slavoj. 2020. Monitor and Punish? Yes, Please! The Philosophical Salon, 16 March 2020, http://thephilosophicalsalon.com/monitor-and-punish-yes-please/

\section{About the Author}

Christian Fuchs

Christian Fuchs is co-editor of the journal tripleC: Communication, Capitalism \& Critique, a critical theorist of society and communication, and author of many books and articles. @fuchschristian; http://fuchsc.net, http://www.triple-c.at 